\title{
Sorption and desorption behavior of lead in four different soils of India
}

\author{
Sudarshan K. Dutta ${ }^{1,2^{\star}}$, Dhanwinder Singh ${ }^{1}$ \\ ${ }^{1}$ Department of Soils, Punjab Agricultural University, Ludhiana, Punjab, India; \\ ${ }^{2}$ Department of Plant and Soil, University of Delaware, Newark, USA; ${ }^{*}$ Corresponding Author: sudarshandutta@gmail.com
}

Received 20 October 2010; revised 11 November 2010; accepted 20 November 2010

\begin{abstract}
Sorption and desorption mechanisms of lead $(\mathrm{Pb})$ were determined in four different soils collected from different agro-climatic regions of India. The soils were classified as: Fine loamy mixed Typic Dystrudepts, fine sandy loam Typic Ustochrepts, fine loamy Typic Ustochrept, and fine sandy loam Udic Haplustalfs. Seven different $\mathrm{Pb}$ solutions $\left[\mathrm{Pb}\left(\mathrm{NO}_{3}\right)_{2}\right.$ dissolved in $0.01 \mathrm{M}$ $\left.\mathrm{Ca}\left(\mathrm{NO}_{3}\right)_{2}\right]$ in a range of 400 to $2000 \mu \mathrm{LL}^{-1}$ were applied to study the sorption amounts at 25$( \pm 2)^{\circ} \mathrm{C}$ and $45( \pm 2)^{\circ} \mathrm{C}$ temperatures. With the increase in application rate and temperature, sorption amounts of $\mathrm{Pb}$ increased; however, percentages of sorption of applied $\mathrm{Pb}$ were decreased. Sorptions were positively and significantly ( $p \leq 0.01)$ correlated with Langmuir adsorption isotherm. Thermodynamic parameters of sorption (i.e. $\mathbf{K}^{\circ}, \Delta \mathbf{G}^{\circ}, \Delta \mathbf{H}^{\circ}$, and $\Delta \mathbf{S}^{\circ}$ ) were also determined at two temperatures, $25( \pm 2)^{\circ} \mathrm{C}$ and $45( \pm 2)^{\circ} \mathrm{C}$. Increase in $\mathrm{K}^{\circ}$ with the increase in temperature indicated positive effect of temperature on $\mathrm{Pb}$ sorption. High absolute values of $\Delta \mathbf{G}^{\circ}$, and positive values of $\Delta \mathrm{H}^{\circ}$, and $\Delta \mathbf{S}^{\circ}$ suggested that the sorption reaction was spontaneous and endothermic. Sorbed $\mathrm{Pb}$ were desorbed in $\mathrm{Pb}$ free $0.01 \mathrm{M} \mathrm{Ca}\left(\mathrm{NO}_{3}\right)_{2}$ solutions at $25( \pm 2)^{\circ} \mathrm{C}$ and $45( \pm 2)^{\circ} \mathrm{C}$. Desorption amounts increased with increase in the $\mathrm{Pb}$ application rate, but not always with the increase in temperature.
\end{abstract}

Keywords: Desorption; Isotherm; Lead; Sorption; Thermodynamics

\section{INTRODUCTION}

Lead $(\mathrm{Pb})$ is a widespread non-biodegradable chemical contaminant found in the soil receiving disposal of city wastes, sewage, and industrial effluents [1]. The bioavailability of $\mathrm{Pb}$ in soil is highly dependent on the sorption (adsorption + precipitation) and desorption behavior of soil [2-4]. Sorption increases the immobility of $\mathrm{Pb}$ while desorption increases the $\mathrm{Pb}$ concentration in soil solution from the sink. Therefore, an understanding of adsorption and desorption processes and their mechanism is crucial for the assessment of the $\mathrm{Pb}$ contamination and the reclamation of such polluted soils [1]. Considerable research has been done on the adsorption behavior of $\mathrm{Pb}$ on different soils. Adhikari and Singh [1] studied the adsorption of $\mathrm{Pb}$ by some Indian soils. Aziz [5] reported the sorption equilibrium of $\mathrm{Pb}$ in two different types of Palestine soils. However, $\mathrm{Pb}$ sorption depends on the chemical and mineralogical characteristics of the soils, and therefore varies among soil types [1]. Therefore, more information related to $\mathrm{Pb}$ sorption in different types of soils with different soil physicochemical properties is always helpful to strengthen our present understanding of sorption.

The sorption of $\mathrm{Pb}$ is controlled by the thermodynamic parameters related to the soil-metal interactions [1]. Therefore, determination of the thermodynamic parameters can assist in the prediction of the final state of metal in the soil system from an initial non-equilibrium state [6]. These thermodynamic parameters include equilibrium constant, $\mathrm{K}^{0}$; standard free energy, $\Delta \mathrm{G}^{0}$; standard enthalpy, $\Delta \mathrm{H}^{\circ}$; and standard entropy, $\Delta \mathrm{S}^{\circ}$. For example, Adhikari and Singh [1] reported that the sorption process can be better expressed by the evaluation of the free energy change $\left(\Delta G^{0}\right)$ corresponding to the transfer of element from bulk solution into soil surface. They also reported that an understanding of the change in enthalpy $\left(\Delta \mathrm{H}^{\circ}\right)$ and entropy $\left(\Delta \mathrm{S}^{\circ}\right)$ helps in determining the free energy change and disorders occurred during sorption process. In the present study, we focused on the sorption of $\mathrm{Pb}$ (II) in four different soils of India, and evaluated the thermodynamic parameters $\left(\mathrm{K}^{\mathrm{o}} ; \Delta \mathrm{G}^{\mathrm{o}} ; \Delta \mathrm{H}^{\mathrm{o}}\right.$; and $\Delta \mathrm{S}^{\circ}$ ) related to the interaction of the metal with soils during sorption. 
Soil can sorb excessive amount of trace metal ions, like $\mathrm{Pb}$, from soil solution, and therefore has drawn attention of a lot of researchers [7]. However, only a few studies are focused on the desorption kinetics of the sorbed trace metals [8]. The thermodynamics related to the sorption and desorption assumed to be different as the sorption reactions involving trace metals are extremely rapid, and desorption reactions can be slower by orders of magnitude [7,9,10]. Moreover, adsorptiondesorption reactions are often not completely reversible, which is known as non-singularity, or hysteresis [7]. On the contrary, number of studies related to $\mathrm{Pb}$ desorption is very limited, especially for Indian soils. Therefore, in the present study we also focused on the desorption characteristics of the sorbed $\mathrm{Pb}$.

Specific questions that were addressed in this study include: 1) How do the sorption amounts of $\mathrm{Pb}$ by the soil vary with the variation in application rate and soil temperature, and how well do they fit with Langmuir adsorption isotherms? 2) How do the thermodynamic parameters $\left(\mathrm{K}^{\mathrm{o}}, \Delta \mathrm{G}^{\mathrm{o}}, \Delta \mathrm{H}^{\mathrm{o}}\right.$, and $\left.\Delta \mathrm{S}^{\mathrm{o}}\right)$ of $\mathrm{Pb}$ sorption vary at two different temperatures? 3) How do the desorptions of added $\mathrm{Pb}$ vary with the initial application rate and soil temperature, and how well do the desorption data fit with the Langmuir desorption isotherm?

\section{MATERIALS AND METHODS}

\subsection{Soil Sampling and Analysis}

Four surface soil samples $(0-15 \mathrm{~cm}$ depth) expected to differ in physicochemical properties, were collected from four different agro-climatic zones (ACZs) of India (based on the classification of Gajbhiye and Mandal, [11]). The samples were collected from Palampur (ACZ 1, Himachal Pradesh; soil type: fine loamy mixed Typic Dystrudepts), Jalandhar (ACZ 6, Punjab, soil type: fine sandy loam Typic Ustochrepts ), Purulia (ACZ 7, West Bengal, soil type: fine loamy Typic Ustochrept), and Pudukkottai (ACZ 11, Tamil Nadu, soil type: fine sandy loam Udic Haplustalfs) during summer (April-June) of 2004. The USDA system of soil classification was used for the determination of soil textural classes. The soil samples were collected mainly from the agricultural fields with no history of receiving $\mathrm{Pb}$ applications. Samples were then air dried, crushed in wooden mortar and pestle, and then passed through a $2 \mathrm{~mm}$ sieve. Then the samples were stored in HDPE (high-density polyethylene) containers in laboratory until analyzed. The details of the measurements of the soil physico-chemical processes were explained elsewhere [12]. Total $\mathrm{Pb}$ values were measured by following the method of Tessier et al. [13]. The DTPA extractable Pb contents were determined by DTPA method [14].

\subsection{Sorption/Desorption Studies}

Batch equilibrium technique was adopted for the $\mathrm{Pb}$ sorption study. Sorption of $\mathrm{Pb}$ at soil was determined by equilibrating the soil samples ( $2 \mathrm{~g}$ of soil samples in duplicate) with $20 \mathrm{ml}$ of $0.01 \mathrm{M}$ calcium nitrate [Ca$\left.\left(\mathrm{NO}_{3}\right)_{2}\right]$ solutions containing seven different concentrations of $\mathrm{Pb}$. The concentrations of $\mathrm{Pb}$ used in our study include 40, 80, 100,120,140,160, and $200 \mu \mathrm{g} \mathrm{ml}^{-1}$ of $\mathrm{Pb}$ (equivalent to $400,800,1000,1200,1400,1600$, and $2000 \mu \mathrm{g} \mathrm{Pb} \mathrm{g}^{-1}$ soil, respectively). We used lead nitrate $\left[\mathrm{Pb}\left(\mathrm{NO}_{3}\right)_{2}\right]$ as a source of $\mathrm{Pb}$. Calcium nitrate $\left[\mathrm{Ca}\left(\mathrm{NO}_{3}\right)_{2}\right]$ was used as the supporting electrolyte for reducing the non-specific adsorption of $\mathrm{Pb}$ [15]. Previous studies also reported a high $(>80 \%)$ reduction of non-specific sorption of heavy metals by using $\mathrm{Ca}\left(\mathrm{NO}_{3}\right)_{2}$ solution [16]. We preferred nitrate $\left(\mathrm{NO}_{3}{ }^{-}\right)$as the electrolyte anion over others (like chloride, $\mathrm{Cl}^{-}$) as $\mathrm{NO}_{3}{ }^{-}$is less likely to form complexes with metal ions $[16,17]$.

To measure the thermodynamic parameters, sorption and desorption experiments were carried out at two different temperatures, $25 \pm 2^{\circ} \mathrm{C}$ and $45 \pm 2^{\circ} \mathrm{C}$. Samples were allowed to equilibrate at two temperatures (in triplicate concentrations as well as temperatures) for $24 \mathrm{hrs}$ followed by a $2 \mathrm{hrs}$ shaking to attain the sorption equilibrium; therefore, the total number of sample was 168 (i.e. 4 soils $\times 3$ replications $\times 7$ concentrations $\times 2$ temperatures). The average values of these 3 replications are presented in this paper. We also performed an initial study prior to actual experiment to find out the time required to attain sorption equilibrium at both temperatures $\left(25 \pm 2{ }^{\circ} \mathrm{C}\right.$ and $\left.45 \pm 2{ }^{\circ} \mathrm{C}\right)$ and observed that sorption did not increase after $2 \mathrm{hrs}$ of shaking. Concentrations of $\mathrm{Pb}$ were measured in these decanted solutions using Avanta PM Flame Atomic Absorption Spectrophotometer (AAS) (GBC Scientific Equipment, Dandenong, Australia). The detection limit of the instrument at lower side was $10 \mu \mathrm{g} \mathrm{L}^{-1}(0.01 \mathrm{ppm})$. Difference in the mass of $\mathrm{Pb}$ in the solutions before and after equilibrium was considered as the amount of $\mathrm{Pb}$ sorbed per $2 \mathrm{~g}$ of soil.

Desorption was determined by measuring the $\mathrm{Pb}$ concentrations in the extracted solutions. Four to six extractions based on a pre-study were performed with pure $(\mathrm{Pb}$ free) $0.01 \mathrm{M} \mathrm{Ca}\left(\mathrm{NO}_{3}\right)_{2}$ solution for the same soil samples used for sorption studies. $\mathrm{Ca}\left(\mathrm{NO}_{3}\right)_{2}$ solution was used for the extraction of the heavy metals (like $\mathrm{Pb}$ ) as this could be a good indicator of the bioavailability of $\mathrm{Pb}$ [1]. The number of extraction required for maximum desorption was decided based on initial experiments performed at both 25 and $45^{\circ} \mathrm{C}$ (described in [12]).

\subsection{Analysis of Sorption and Desorption Data Using Langmuir Adsorption Isotherms}

To further our understanding of sorption and desorp- 
tion processes, we fitted our $\mathrm{Pb}$ sorption and desorption data to Langmuir adsorption and desorption isotherms. The details of data analyses steps were described in Adhikari and Singh [1]. In short, Langmuir adsorption isotherm was used to calculate the adsorption parameters, such as: Adsorption maxima ' $b$ ', and bonding energy coefficient, ' $\mathrm{K}$ '. The conventional form of the Langmuir adsorption isotherm of $\mathrm{Pb}$ can be written as: $\mathrm{C}_{\mathrm{e}} /(\mathrm{x} / \mathrm{m})=$ $1 /\left(\right.$ K.b) $+\mathrm{C}_{\mathrm{e}} / \mathrm{b}$ (Eq. 1).

Where, $\mathrm{C}_{\mathrm{e}}$ is the equilibrium $\mathrm{Pb}$ concentration $(\mathrm{mg}$ $\left.\mathrm{L}^{-1}\right), \mathrm{x} / \mathrm{m}$ is the amount of $\mathrm{Pb}$ adsorbed by soil $\left(\mathrm{mg} \mathrm{kg}^{-1}\right)$, ' $b$ ' and ' $K$ ' are Langmuir constants. The constant ' $K$ ' is related to the bonding energy of the adsorbent for the $\mathrm{Pb}$ $\left(\mathrm{L} \mathrm{mg}^{-1}\right)$.

The Langmuir isotherm (Eq. 1) is a straight line where $\mathrm{C}_{\mathrm{e}} /(\mathrm{x} / \mathrm{m})$ were plotted against $\mathrm{C}_{\mathrm{e}}$. The best fit values of the coefficients ' $b$ ' and ' $K$ ' were derived using the isotherm equations, where $\mathrm{b}=1$ /slope, and $\mathrm{K}=$ slope/ intercept.

Cumulative $\mathrm{Pb}$ desorption data were fitted to a modified Langmuir desorption isotherm, which can be written as: $D_{\mathrm{e}} / \mathrm{R}=1 / \mathrm{K}_{\mathrm{d}} \mathrm{D}_{\mathrm{m}}+\mathrm{D}_{\mathrm{e}} / \mathrm{D}_{\mathrm{m}}$ (Eq. 2).

Here, $\mathrm{D}_{\mathrm{e}}$ is the concentration of $\mathrm{Pb}$ desorbed $\left(\mathrm{mg} \mathrm{L}^{-1}\right)$, and $D_{m}$ is the desorption maxima ( $\mathrm{mg} \mathrm{kg}^{-1}$ soil). $\mathrm{R}$ is the amount of $\mathrm{Pb}$ desorbed per gram of soil ( $\mu \mathrm{gg}^{-1}$ soil), $\mathrm{K}_{\mathrm{d}}$ is the constant related to the mobility of lead. $D_{m}$ and $K_{d}$ were calculated from the linear plots of $D_{e}$ versus $D_{e} / R$. Previous studies [18] also applied this equation in their $\mathrm{Pb}$ desorption studies in different soils of Punjab, India.

\subsection{Analysis of Thermodynamic Parameters}

The $\mathrm{Pb}$ sorption data obtained at two different temperatures $\left(25 \pm 2^{\circ} \mathrm{C}\right.$ and $\left.45 \pm 2^{\circ} \mathrm{C}\right)$ were used to measure the thermodynamic properties of the reactions. Among the different thermodynamic parameters, the variation of thermodynamic equilibrium constant $\left(\mathrm{K}^{\mathrm{o}}\right)$ were computed following the procedure described by Adhhikari and Singh [1].

The value of $\mathrm{K}^{\mathrm{o}}$ for the adsorption reaction can be expressed as: $\mathrm{K}^{\mathrm{o}}=\mathrm{a}_{\mathrm{s}} / \mathrm{a}_{\mathrm{e}}=\gamma_{\mathrm{s}} \mathrm{C}_{\mathrm{s}} / \gamma_{\mathrm{e}} \mathrm{C}_{\mathrm{e}}$ (Eq. 3).

Where, $a_{s}$ denotes activity of adsorbed metal, $a_{e}$ is the activity of metal in equilibrium solution. $\mathrm{C}_{\mathrm{s}}$ is the amount (milligrams) of metal adsorbed per unit volume (liter) of solution in contact with the adsorbent surfaces, $\mathrm{C}_{\mathrm{e}}$ is the amount (milligrams) of solute per unit volume (liter) of solution in contact with the adsorbent surfaces at equilibrium, $\gamma_{\mathrm{s}}$ is the activity coefficient of the sorbed metals, and $\gamma_{\mathrm{e}}$ denotes the activity coefficient of metal at equilibrium. In physical chemistry it is assumed that with the lowering of concentration $\left(\mathrm{C}_{\mathrm{s}}\right.$ and $\left.\mathrm{C}_{\mathrm{e}}\right)$, the activity coefficients $\left(\gamma_{\mathrm{s}}\right.$ and $\left.\gamma_{\mathrm{e}}\right)$ approach unity. Therefore, the equation becomes: $\mathrm{K}^{\mathrm{o}}=\mathrm{C}_{\mathrm{s}} / \mathrm{C}_{\mathrm{e}}$ (Eq. 4).
The $\mathrm{K}^{\mathrm{o}}$ values were determined by plotting $\ln \left(\mathrm{C}_{\mathrm{s}} / \mathrm{C}_{\mathrm{e}}\right)$ versus $\mathrm{Cs}$ and extrapolating to $\mathrm{Cs}=0$. The standard free energy $\left(\Delta G^{0}\right)$ was determined by using the following equation: $\left(\Delta \mathrm{G}^{\mathrm{o}}\right)=-\mathrm{R} \mathrm{T} \ln \mathrm{K}^{\mathrm{o}}$ (Eq. 5).

The standard enthalpy $\left(\Delta \mathrm{H}^{\circ}\right)$ was obtained by using the integrated Vant Hoff equation:

$\ln \mathrm{K}_{2}{ }^{\mathrm{o}} / \mathrm{K}_{1}{ }^{\mathrm{o}}=\Delta \mathrm{H}^{\mathrm{o}} / \mathrm{R}\left[1 / \mathrm{T}_{1}-1 / \mathrm{T}_{2}\right]$ (Eq. 6).

The standard entropy $\left(\Delta \mathrm{S}^{\circ}\right)$ was measured as:

$\Delta \mathrm{S}^{\mathrm{o}}=\left(\Delta \mathrm{H}^{\mathrm{o}}-\Delta \mathrm{G}^{\mathrm{o}}\right) / \mathrm{T}$ (Eq. 7).

Statistical operations were performed using the statistical software JMP (Version 8, SAS Institute Inc., Cary, $\mathrm{NC}, \mathrm{USA}$ )

\section{RESULTS AND DISCUSSION}

\subsection{Physicochemical Properties of the Experimental Soils}

The physicochemical properties of the four experimental soils have been described in Table 1. The $\mathrm{pH}$ of the soils ranged from 5.6 to 6.2 ; EC values were from 0.08 to $0.15 \mathrm{dSm}^{-1}$; CEC varied from 11.5 to $23.4 \mathrm{cmol}$ $\left(\mathrm{p}^{+)}\right.$per $\mathrm{kg}$ soil; clay contents were from 15 to $22 \%$, and $\%$ organic $\mathrm{C}$ ranged from 0.29 to $0.91 \%$. The experimental soils were non-calcareous and therefore did not have any $\mathrm{CaCO}_{3}$. Total native $\mathrm{Pb}$ content of the soils varied from 16.8 to $34.8 \mu \mathrm{g} \mathrm{g}^{-1}$ soil; whereas, the DTPA $\mathrm{Pb}$ content ranged from 0.21 to $1.48 \mu \mathrm{gg}^{-1}$ (Table 1). The percentage of labile $\mathrm{Pb}$, i.e. amount of $\mathrm{Pb}$ over total native $\mathrm{Pb}$ varied from 1.3 to $7.4 \%$. Overall, the soils varied in their physicochemical characteristics; and expected to show variation in sorption and desorption amounts of $\mathrm{Pb}$.

\subsection{Variation of $\mathbf{P b}$ Sorption with $\mathbf{P b}$ Application Rate and Temperature}

All the soil samples exhibited high capacities to sorb $\mathrm{Pb}$ at both $25( \pm 2)^{\circ} \mathrm{C}$ and $45( \pm 2)^{\circ} \mathrm{C}$. The amounts of $\mathrm{Pb}$ sorption with varying application rates $(400,800,1000$, $1200,1400,1600$, and $2000 \mu^{-1}$ soil) have been reported in Table 3. We observed that, with increase in $\mathrm{Pb}$ concentrations from 400 to $2000 \mathrm{\mu gg}^{-1}$ soil, the amount of $\mathrm{Pb}$ sorption also increased in all the four soils (Table 2).

This was expected because more $\mathrm{Pb}$ was available for sorption on soil with the increase in application. However, the percentage of $\mathrm{Pb}$ sorbed on soils decreased. This was also expected because the availability of the binding sites decreased with the increase in concentration. Previous studies also reported an increase in $\mathrm{Pb}$ sorption with the increase in application rate. Shaheen et al. [19] observed $\mathrm{Pb}$ sorption in 11 different types of soils. They found increase in $\mathrm{Pb}$ sorption with the increase in $\mathrm{Pb}$ application rate from 1 to $4 \mathrm{~m} \mathrm{ML}^{-1}$; however, they reported de- 
Table 1. Physicochemical properties and total $(\mathrm{Pb})$ contents of the collected soil samples.

\begin{tabular}{|c|c|c|c|c|c|c|c|c|c|c|c|}
\hline $\begin{array}{c}\text { Sampling Loca- } \\
\text { tion } \\
\text { /Soil type }\end{array}$ & $\mathrm{pH}$ & $\begin{array}{c}E C \\
\left(\mathrm{dS} \mathrm{m}^{-1}\right)\end{array}$ & $\begin{array}{c}\text { Organic } \\
\text { Carbon (\%) }\end{array}$ & $\begin{array}{c}\mathrm{CaCO}_{3} \\
(\%)\end{array}$ & $\begin{array}{c}\text { CEC } \\
\left(\mathrm{cmol}\left(\mathrm{p}^{+}\right) / \mathrm{kg}\right. \\
)\end{array}$ & $\begin{array}{l}\text { Sand } \\
(\%)\end{array}$ & $\begin{array}{l}\text { Silt } \\
(\%)\end{array}$ & $\begin{array}{l}\text { Clay } \\
(\%)\end{array}$ & $\begin{array}{l}\text { Total Pb } \\
\left(\mu \mathrm{g} \mathrm{g}^{-1}\right)\end{array}$ & $\begin{array}{c}\text { DTPA } \\
\mathrm{Pb} \\
\left(\mu \mathrm{g} \mathrm{g}^{-1}\right)\end{array}$ & $\begin{array}{l}\text { Labile } \\
\mathrm{Pb}(\%)\end{array}$ \\
\hline $\begin{array}{l}\text { Palampur } \\
\text { (Fine loamy } \\
\text { mixed Typic } \\
\text { Dystrudepts) }\end{array}$ & 6.2 & 0.08 & 0.91 & $\mathrm{ND}^{*}$ & 22.9 & 64.5 & 12 & 22 & 34.8 & 1.31 & 3.8 \\
\hline $\begin{array}{l}\text { Jalandhar } \\
\text { (Fine sandy loam } \\
\text { Typic Usto- } \\
\text { chrepts) }\end{array}$ & 5.6 & 0.08 & 0.60 & ND & 23.4 & 80.9 & 5 & 15 & 20.1 & 1.48 & 7.4 \\
\hline $\begin{array}{c}\text { Purulia } \\
\text { (Fine loamy Typic } \\
\text { Ustochrept) }\end{array}$ & 6.1 & 0.15 & 0.48 & ND & 17.9 & 47.8 & 33 & 19 & 24.9 & 0.94 & 3.8 \\
\hline $\begin{array}{c}\text { Pudukkottai } \\
\text { (Fine sandy loam } \\
\text { Udic Haplustalfs) }\end{array}$ & 6.1 & 0.09 & 0.29 & ND & 11.5 & 73.0 & 6 & 20 & 16.8 & 0.21 & 1.3 \\
\hline
\end{tabular}

Table 2. Amount and percentage of $\mathrm{Pb}$ sorbed $\left(\mu \mathrm{g} \mathrm{g}^{-1}\right)$ at four different soils receiving seven different initial $\mathrm{Pb}$ treatments at two different temperatures $\left(25 \pm 2^{\circ} \mathrm{C}\right.$ and $\left.45 \pm 2^{\circ} \mathrm{C}\right)$.

\begin{tabular}{|c|c|c|c|c|c|c|c|}
\hline \multirow{2}{*}{$\begin{array}{l}\text { Sampling } \\
\text { locations }\end{array}$} & \multicolumn{7}{|c|}{ Amount of $\mathrm{Pb}$ applied per gram soil $\left(\mu \mathrm{g} \mathrm{g}^{-1}\right)$ at $25( \pm 2)^{\circ} \mathrm{C}$} \\
\hline & 400 & 800 & 1000 & 1200 & 1400 & 1600 & 2000 \\
\hline Palampur & $381.6(96.5)$ & $757.6(94.7)$ & $927.1(92.7)$ & $1100.191 .7)$ & $1268.9(90.0)$ & $1427.8(89.1)$ & $1763.4(88.2)$ \\
\hline Jalandhar & $368.2(92.05)$ & $732.0(91.5)$ & $889.6(89.1)$ & $1057.8(88.1)$ & $1221.1(87.2)$ & $1349.5(84.3)$ & $1670.0(83.5)$ \\
\hline Purulia & $386.6(96.7)$ & $758.1(94.8)$ & $921.8(92.2)$ & $1066.3(88.9)$ & $1179.1(84.2)$ & $1334.1(83.4)$ & $1629.8(81.5)$ \\
\hline Pudukkottai & 355.4 (88.9) & $678.9(84.9)$ & $803.8(80.4)$ & 934.3 (77.9) & $991.6(70.83)$ & $1054.6(65.3)$ & $1216.3(60.8)$ \\
\hline \multicolumn{8}{|c|}{ Amount of $\mathrm{Pb}$ applied per gram soil $\left(\mu \mathrm{g} \mathrm{g}^{-1}\right)$ at $45( \pm 2)^{\circ} \mathrm{C}$} \\
\hline Palampur & $395.6(98.9)$ & $786.6(98.5)$ & $965.0(96.5)$ & $1154.4(96.3)$ & $1320.9(94.4)$ & $1480.6(92.5)$ & $1845.1(92.3)$ \\
\hline Jalandhar & 397.7 (94.9) & $755.2(94.4)$ & $930.2(93.0)$ & $1115.1(92.9)$ & $1283.1(91.7)$ & $1455.6(91.0)$ & $1802.8(90.1)$ \\
\hline Purulia & 389.1 (97.3) & $766.3(95.8)$ & $929.5(93.0)$ & $1111.8(92.6)$ & $1271.2(90.8)$ & $1435.6(89.7)$ & $1668.8(83.4)$ \\
\hline Pudukkottai & $367.5(91.8)$ & $689.6(86.2)$ & $830.8(83.1)$ & $993.5(82.8)$ & $1055.0(77.1)$ & $1155.0(72.2)$ & $1269.4(63.2)$ \\
\hline
\end{tabular}

(Figures within parentheses denote percent of $\mathrm{Pb}$ sorption)

Table 3. Langmuir adsorption isotherms, correlation coefficients, and Langmuir parameters for four experimental soils at two different temperatures.

\begin{tabular}{|c|c|c|c|c|}
\hline $\begin{array}{c}\text { Sampling locations } \\
\text { At } 25( \pm 2)^{\circ} \mathrm{C}\end{array}$ & Linear Langmuir equations & $\begin{array}{c}\text { Correlations of } \\
\text { equations (R) }\end{array}$ & $\begin{array}{l}\text { Adsorption maxima } \\
\text { (b) }\left(\mathrm{mg} \mathrm{kg}^{-1}\right)\end{array}$ & $\begin{array}{c}\text { Bonding energy coeffi- } \\
\text { cient }(\mathrm{k})(\mathrm{L} / \mathrm{mg})\end{array}$ \\
\hline Palampur & $y=0.442 x+5.165$ & $0.97 *$ & 2.26 & 0.086 \\
\hline Jalandhar & $y=0.379 x+8.731$ & $0.93 *$ & 2.39 & 0.043 \\
\hline Purulia & $y=0.697 x+2.682$ & $0.99 *$ & 1.44 & 0.259 \\
\hline Pudukkottai & $y=0.701 x+11.207$ & $0.99 *$ & 1.43 & 0.063 \\
\hline \multicolumn{5}{|l|}{ At $45( \pm 2)^{\circ} \mathrm{C}$} \\
\hline Palampur & $y=0.508 x+1.397$ & $0.98 *$ & 1.97 & 0.360 \\
\hline Jalandhar & $y=0.335 x+4.797$ & $0.98 *$ & 2.99 & 0.070 \\
\hline Purulia & $y=0.501 x+3.059$ & $0.99 *$ & 1.99 & 0.164 \\
\hline Pudukkottai & $y=0.692 x+7.797$ & $0.99 *$ & 1.54 & 0.088 \\
\hline
\end{tabular}

* Statistically significant at $\mathrm{p} \leq 0.01$.

crease in $\mathrm{Pb}$ sorption percentage due to less availability of binding space.

Although we observed increase in $\mathrm{Pb}$ sorption with increase in application rates for all the four experimental soils, there were variations in the sorption amounts. The sorption trend was Typic Dystrudepts > Typic Ustochrepts (loamy sand) $>$ Typic Ustochrept (loamy) $>$ Typic Haplustalfs (i.e. Palampur soil $>$ Jalandhar soil $>$ Purulia soil $>$ Pudukkottai soil) at all concentrations. This variation might be a consequence of the variation in the \% organic $\mathrm{C}$, and $\mathrm{CEC}$ values of the soils. The \% Organic $\mathrm{C}$ and $\mathrm{CEC}$ values were also higher for Palampur and Jalandhar soils as compared to that of Purulia and Pudukkottai soils (Table 1). Previous studies also reported that $\%$ organic $\mathrm{C}$, and $\mathrm{CEC}$ played important roles in $\mathrm{Pb}$ sorption [2,4,20,21]. Singh and Sekhon [18] observed a significant correlation of sorption maxima with CEC, clay contents, and \% organic C for some of the Punjab soils. Adhikari and Singh [1] reported that variations in sorption maxima were correlated with the 
$\mathrm{pH}, \mathrm{CEC}$, and organic carbon contents of the soils.

The effect of temperature on the amount of $\mathrm{Pb}$ sorption can also be observed in Table 2 . We found that $\mathrm{Pb}$ sorption and percentage of applied $\mathrm{Pb}$ sorbed increased with increase in temperature from $25^{\circ} \mathrm{C}$ to $45^{\circ} \mathrm{C}$ at all the levels of $\mathrm{Pb}$ application (Table 2). Adhikari and Singh [1] also reported an increase in $\mathrm{Pb}$ sorption with increase in temperature from $25^{\circ} \mathrm{C}$ to $45^{\circ} \mathrm{C}$. They concluded that the $\mathrm{Pb}$ sorption reaction was endothermic which resulted in an increase in $\mathrm{Pb}$ sorption with the increase in the temperature.

We also compared the sorption isotherms at the two different temperatures with the different solute sorption isotherms based on the classification of Giles et al. [22]. According to Giles et al. [22], there are four different solute sorption isotherms: namely ' $S$ ', ' $L$ ', ' $H$ ', and ' $C$ ' curves; and each of them corresponds to a different solute/sorbent interaction. They mentioned that the shape of these isotherms also provide information related to the strength by which the sorbate is held/attached to the soil. $\mathrm{The} \mathrm{Pb}$ sorption isotherms of our four experimental soils were presented in Figures 1(a)-(d). By comparing our present graphs with Giles et al. [22], we observed ' $L$ ' type of curve for all the four soils at $25^{\circ} \mathrm{C}$ temperature (Figure 1(a)-(d)). However, in $45^{\circ} \mathrm{C}$, the curve types varied among the soils. In Palampur and Jalandhar soils, the sorption isotherms were approaching to be ' $\mathrm{H}$ ' type
(Figure 1(a), (b)); whereas, for Purulia and Pudukottai soils, the sorption isotherms were ' $L$ ' type (Figure 1(c), (d)). According to Giles et al. [22], 'L' type of curves corresponds to a strong affinity between metallic cations and the sorbent surface, which favors specific sorption. On the other hand, ' $\mathrm{H}$ ' type of curve indicates strong sorbate-substrate attraction force and may lead to precipitation. Martinez-Villegas et al. [17] also observed the same $\mathrm{Pb}$ sorption isotherm pattern with the increase in $\mathrm{Pb}$ concentrations from 10 to $400 \mathrm{mg} \mathrm{L}^{-1}$ in different Mexican soils.

\section{3. $\mathrm{Pb}$ Sorption and Langmuir Adsorption Isotherm}

The $\mathrm{Pb}$ sorption data were fitted to the Langmuir and Freundlich adsorption isotherms. In the case of Langmuir adsorption isotherm, we observed that the sorption data fitted significantly $(\mathrm{p} \leq 0.01)$ in the isotherms for all the experimental soils and at both $25^{\circ} \mathrm{C}$ and $45^{\circ} \mathrm{C}$ temperatures (Table 3). The observed correlations were also high ( $\mathrm{R}=0.93$ to 0.99 ) (Table 3). Previous studies also reported significant correlations of their sorption data and the Langmuir adsorption isotherms [18,23]. For example, Singh and Sekhon, [18] described that their $\mathrm{Pb}$ sorption in alkaline soils fitted significantly $(\mathrm{p} \leq 0.05)$ with Langmuir adsorption isotherm. In all of our ex-

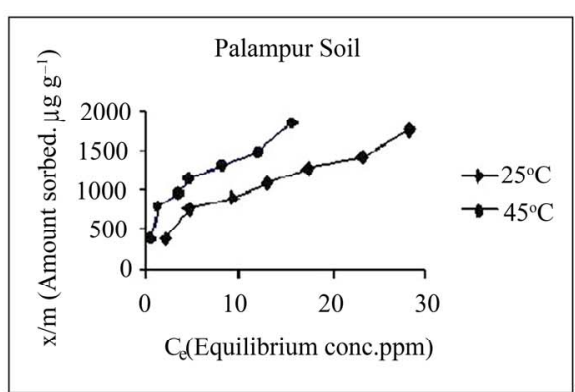

(a)

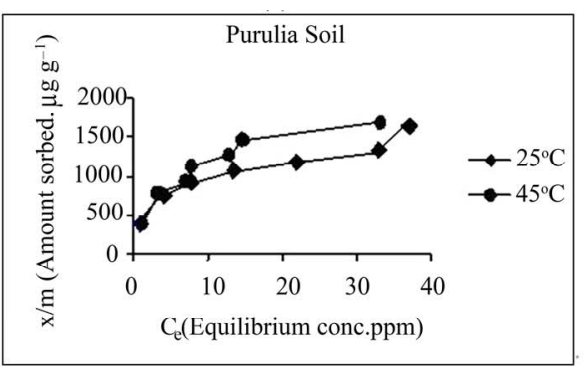

(c)

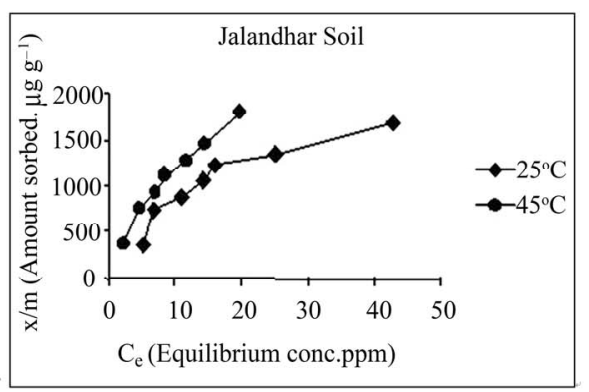

(b)

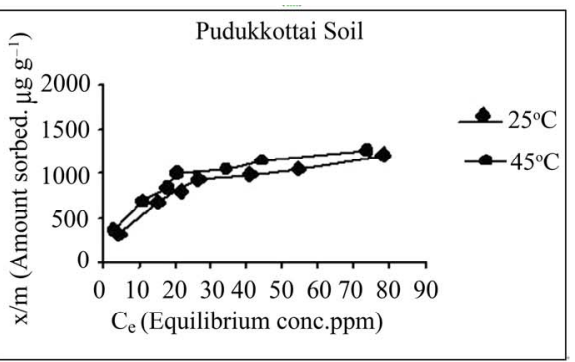

(d)

Figure 1. (a) Lead sorption isotherms for Palampur soil. At $25^{\circ} \mathrm{C}$ the sorption isotherm is ' $\mathrm{L}$ ' type, and at $45^{\circ} \mathrm{C}$ the isotherm trends towards ' $\mathrm{H}$ ' type. (b) Lead sorption isotherms for Jalandhar soil. At $25^{\circ} \mathrm{C}$ the sorption isotherm is ' $\mathrm{L}$ ' type, and at $45^{\circ} \mathrm{C}$ the isotherm is ' $\mathrm{H}$ ' type. (c) Lead sorption isotherms for Purulia soil. At both $25^{\circ} \mathrm{C}$ and $45^{\circ} \mathrm{C}$ the sorption isotherm is ' $\mathrm{L}$ ' type. (d) Lead sorption isotherms for Pudukkottai soil. At both $25^{\circ} \mathrm{C}$ and $45^{\circ} \mathrm{C}$ the sorption isotherm is ' $\mathrm{L}$ ' type. 
perimental soils, we observed that the Langmuir adsorption maxima (' $b$ ') increased with the increase in temperature from $25^{\circ} \mathrm{C}$ to $45^{\circ} \mathrm{C}$ (Table 3). The ' $b$ ' values were in the order of Jalandhar soil > Palampur soil $>$ Purulia soil $>$ Pudukkottai soil at both the temperatures. The physicochemical properties of the Jalandhar soil and the Palampur soil were almost similar and might have resulted in similar ' $b$ ' values $\left(2.26\right.$ and $2.39 \mu \mathrm{gml}^{-1}$, respectively). The higher ' $b$ ' values for Palampur and Jalandhar soils compared to Purulia and Pudukkottai soil can be attributed to the higher \% organic $\mathrm{C}$, and $\mathrm{CEC}$ values of these soils. Soil CEC and \% organic $\mathrm{C}$ play important role in $\mathrm{Pb}$ sorption [4,12]. Adhikari and Singh [1] also reported highest $\mathrm{Pb}$ sorption maxima for the soil which had the highest CEC, and \% organic $\mathrm{C}$ contents among their experimental soils. The bonding energy coefficient $(\mathrm{k})$ of experimental soils varied from 0.043 to $0.259 \mathrm{~L} \mathrm{mg}^{-1}$ at $25^{\circ} \mathrm{C}$; and with the increase in temperature to $45^{\circ} \mathrm{C}$, the ' $\mathrm{k}$ ' values also increased (Table 3). Adhikari and Singh [1] also studied sorption of $\mathrm{Pb}$ in four different soils of India at 25 and $45^{\circ} \mathrm{C}$ and reported the range of bonding energy coefficient $(\mathrm{k})$ from 0.094 to $0.135 \mathrm{~L} \mathrm{mg}^{-1}$.

\subsection{Thermodynamic Parameters of $\mathrm{Pb}$ Sorption in Soils}

The thermodynamic parameters which include thermodynamic equilibrium constant $\left(\mathrm{K}^{\circ}\right)$, standard free energy $\left(\Delta \mathrm{G}^{\mathrm{o}}\right)$, standard enthalpy $\left(\Delta \mathrm{H}^{\circ}\right)$, and standard entropy $\left(\Delta \mathrm{S}^{\circ}\right)$, provide an insight into the $\mathrm{Pb}$ sorption mechanism in the soils [1]. We calculated all these mentioned parameters at both $25^{\circ} \mathrm{C}$ to $45^{\circ} \mathrm{C}$ (Table 4). We observed that, ' $\mathrm{K}^{\mathrm{o}}$ ' increased with a rise in the temperature from $25^{\circ} \mathrm{C}$ to $45^{\circ} \mathrm{C}$ for all the four soils. The calculated free energy $\left(\Delta G^{\circ}\right)$ values were negative. Since the negative ' $\Delta \mathrm{G}^{\mathrm{o}}$ ' denotes the amount of energy diminished or required before reaching equilibrium, therefore, more negative ' $\Delta \mathrm{G}^{\mathrm{o}}$ ' value indicates more $\mathrm{Pb}$ sorption [1]. We also observed the highest amount of $\mathrm{Pb}$ sorption in our Palampur soil which had the highest absolute value of ' $\Delta \mathrm{G}^{\mathrm{o}}$ '. Moreover, in all the experimental soils, the ' $\Delta \mathrm{G}^{\mathrm{o}}$ ' values were more negative at a higher temperature, which suggested more spontaneity of the sorption reaction at a higher temperature [6]. The values of isosteric heat or enthalpy $\left(\Delta \mathrm{H}^{\mathrm{o}}\right)$ of $\mathrm{Pb}$ sorption were positive ranging from 27.5 to $92.9 \mathrm{KJ} \mathrm{mol}^{-1}$. This suggests that the $\mathrm{Pb}$ sorption reactions are endothermic in nature. Previous studies [1] also found good correlation between the thermodynamic parameters $\left(\Delta \mathrm{G}^{\mathrm{o}}\right.$, and $\left.\Delta \mathrm{H}^{\mathrm{o}}\right)$, and the soil physico-chemical properties $(\mathrm{pH}, \mathrm{CEC}$, and \% organic $C)$ of the soils. The standard entropy $\left(\Delta S^{\circ}\right)$ values for all the four soils at both the temperatures were positive ranging from 112.61 to $348.12 \mathrm{~J} \mathrm{~mole}^{-1} \mathrm{~K}^{-1}$ at $25^{\circ} \mathrm{C}$ and 107.42 to $334.68 \mathrm{~J} \mathrm{~mole}^{-1} \mathrm{~K}^{-1}$ at $45^{\circ} \mathrm{C}$ (Table 4). Adhikari and Singh, [1] also reported a decrease in $\Delta \mathrm{S}^{\circ}$ with increase in temperature and suggested that, the disorder in the sorption process was lower at higher temperature.

\subsection{How does Pb Desorption Vary with Initial Application Rate and Temperature}

The cumulative desorption of sorbed $\mathrm{Pb}$ increased with the increase in the rate of application in all the experimental soils (Table 5). The percentage of the $\mathrm{Pb}$ desorbed from the amount sorbed also increased with $\mathrm{Pb}$ application rate (Table 5). Padmanabham [24] suggested that, with the increase in $\mathrm{Pb}$ concentrations, the available sites for $\mathrm{Pb}$ binding become lower and the required bonding energies for the $\mathrm{Pb}$ sorption become higher; therefore, a larger amount of applied $\mathrm{Pb}$ become available for desorption. The $\mathrm{Pb}$ desorption data followed the pattern of Pudukkottai soil $>$ Purulia soil $>$ Jalandhar soil $>$ Palampur soil. Therefore, we observed an overall opposite trend between the sorption and desorption data for our four experimental soils; i.e. the soils having higher sorption of $\mathrm{Pb}$, desorbed less and vice-versa. It emphasizes that, sorption and desorption does not follow the same patterns [7,8]. However, we did not observe any certain pattern in $\mathrm{Pb}$ desorption with the increase in temperature.

We hypothesize that, at high application rates some of the $\mathrm{Pb}$ might get physically precipitated instead of chemically bonded and therefore, a portion of sorbed $\mathrm{Pb}$ did not show any certain desorption pattern.

\section{6. $\mathrm{Pb}$ Desorption Isotherm}

We fitted $\mathrm{Pb}$ desorption data with Langmuir desorption equations for the experimental soils at both $25^{\circ} \mathrm{C}$ and $45^{\circ} \mathrm{C}$ (Table 6). We found the desorption data fitted well with the Langmuir desorption isotherms. We found high and significant correlation $(\mathrm{p} \leq 0.01)$ among the $\mathrm{Pb}$ de-

Table 4. Thermodynamic parameters for $\mathrm{Pb}$ sorption in four experimental soils at two different temperatures $\left(25 \pm 2^{\circ} \mathrm{C}\right.$ and $\left.45 \pm 2^{\circ} \mathrm{C}\right)$.

\begin{tabular}{|c|c|c|c|c|c|c|c|}
\hline \multirow{2}{*}{ Sampling locations } & \multicolumn{2}{|c|}{$\mathrm{K}^{\mathrm{o}}$} & \multicolumn{2}{|c|}{$\Delta \mathrm{G}^{\mathrm{o}}\left(\mathrm{kJ} \mathrm{mol}^{-1}\right)$} & \multirow{2}{*}{$\Delta \mathrm{H}^{\mathrm{o}}\left(\mathrm{kJ} \mathrm{mol}^{-1}\right)$} & \multicolumn{2}{|c|}{$\Delta \mathrm{S}^{\mathrm{o}}\left(\mathrm{J} \mathrm{mol}^{-1} \mathrm{~K}^{-1}\right)$} \\
\hline & $25( \pm 2)^{\circ} \mathrm{C}$ & $45( \pm 2)^{\circ} \mathrm{C}$ & $25( \pm 2)^{\circ} \mathrm{C}$ & $45( \pm 2)^{\circ} \mathrm{C}$ & & $25( \pm 2)^{\circ} \mathrm{C}$ & $45( \pm 2)^{\circ} \mathrm{C}$ \\
\hline Palampur & 152.24 & 161.04 & -10.75 & -13.44 & 92.9 & 348.12 & 334.68 \\
\hline Jalandhar & 72.99 & 73.63 & -10.03 & -11.37 & 38.5 & 163.76 & 156.82 \\
\hline Purulia & 23.42 & 25.52 & -7.81 & -8.56 & 33.8 & 139.63 & 133.21 \\
\hline Pudukkottai & 25.97 & 26.47 & -6.07 & -6.66 & 27.5 & 112.61 & 107.42 \\
\hline
\end{tabular}


Table 5. Amount of $\mathrm{Pb}$ desorbed $\left(\mu \mathrm{g} \mathrm{g}^{-1}\right)$ and percentage of desorbed $\mathrm{Pb}$ over sorption at four different soils receiving seven different initial $\mathrm{Pb}$ treatments at two different temperatures $\left(25 \pm 2^{\circ} \mathrm{C}\right.$ and $\left.45 \pm 2^{\circ} \mathrm{C}\right)$.

\begin{tabular}{cccccccc}
\hline \multirow{2}{*}{$\begin{array}{l}\text { Sampling } \\
\text { locations }\end{array}$} & \multicolumn{7}{l}{ Amount of $\mathrm{Pb}$ applied per gram soil $\left(\mu \mathrm{g} \mathrm{g} \mathrm{g}^{-1}\right)$ at $25( \pm 2)^{\circ} \mathrm{C}$} \\
\cline { 2 - 7 } & 400 & 800 & 1000 & 1200 & 1400 & 1600 & 2000 \\
\hline Palampur & $4.1(1.1)$ & $75.8(10)$ & $103.9(11.2)$ & $136.5(12.4)$ & $184.2(14.5)$ & $289.9(20.3)$ & $360.8(20.5)$ \\
Jalandhar & $7.8(2.1)$ & $88.3(12.1)$ & $122.8(13.8)$ & $163.9(15.5)$ & $217.7(17.8)$ & $262.8(19.5)$ & $376.1(22.5)$ \\
Purulia & $7.9(2)$ & $92.2(12.2)$ & $164.4(17.8)$ & $257.1(24.1)$ & $320.2(27.2)$ & $424.5(31.8)$ & $500.4(30.7)$ \\
Pudukkottai & $11.9(3.3)$ & $123.2(18.1)$ & $234.2(29.2)$ & $304.9(32.6)$ & $339.3(34.2)$ & $379.1(35.9)$ & $460.4(37.9)$ \\
At 45 $( \pm 2)^{\circ} \mathrm{C}$ & & & & & & & \\
Palampur & $4.8(1.2)$ & $42.8(5.4)$ & $82.8(8.6)$ & $106.5(9.2)$ & $161.4(12.2)$ & $202.1(13.6)$ & $311.7(16.9)$ \\
Jalandhar & $22.9(5.8)$ & $72.2(9.6)$ & $106.8(11.5)$ & $166.8(14.9)$ & $240.2(18.7)$ & $308.4(21.2)$ & $484.6(26.9)$ \\
Purulia & $13.2(3.4)$ & $60.1(7.8)$ & $100.9(10.9)$ & $147.5(13.3)$ & $223.1(17.6)$ & $306.3(21.3)$ & $411.6(24.7)$ \\
Pudukkottai & $23.9(6.5)$ & $126.1(18.3)$ & $205.5(24.7)$ & $287.4(28.9)$ & $339.9(32.2)$ & $394.9(34.2)$ & $486.2(38.3)$ \\
\hline
\end{tabular}

(Figures within parentheses denote percent of $\mathrm{Pb}$ desorbed from the $\mathrm{Pb}$ sorbed during sorption study)

Table 6. Langmuir desorption equations, correlation coefficients and Langmuir parameters for various soils at $25( \pm 2)^{\circ} \mathrm{C}$ and $45( \pm 2)^{\circ} \mathrm{C}$.

\begin{tabular}{|c|c|c|c|c|}
\hline Sampling locations & Linear Langmuir equation & $\begin{array}{l}\text { Correlation of equations } \\
\text { (R) }\end{array}$ & $\begin{array}{l}\text { Desorption maxima } \\
\mathrm{D}_{\mathrm{m}}\left(\mathrm{mg} \mathrm{kg}^{-1}\right)\end{array}$ & $\begin{array}{l}\text { Desorption coefficient } \\
\qquad \mathrm{K}_{\mathrm{d}}(\mathrm{L} / \mathrm{mg})\end{array}$ \\
\hline \multicolumn{5}{|l|}{ At $25( \pm 2)^{\circ} \mathrm{C}$} \\
\hline Palampur & $y=0.005 x+0.045$ & $0.95 *$ & 182.62 & 0.116 \\
\hline Jalandhar & $y=0.005 x+0.058$ & $0.96^{*}$ & 192.31 & 0.10 \\
\hline Purulia & $y=0.006 x+0.059$ & $0.95 *$ & 166.67 & 0.101 \\
\hline Pudukkottai & $y=0.007 x+0.087$ & $0.95 *$ & 136.99 & 0.084 \\
\hline \multicolumn{5}{|l|}{ At $45( \pm 2)^{\circ} \mathrm{C}$} \\
\hline Palampur & $\mathrm{y}=0.005 \mathrm{x}+0.032$ & $0.96^{*}$ & 204.08 & 0.152 \\
\hline Jalandhar & $y=0.005 x+0.066$ & $0.99 *$ & 222.22 & 0.068 \\
\hline Purulia & $y=0.005 x+0.047$ & $0.98 *$ & 192.31 & 0.111 \\
\hline Pudukkottai & $y=0.007 x+0.085$ & $0.97 *$ & 149.25 & 0.080 \\
\hline
\end{tabular}

* Statistically significant at $\mathrm{p} \leq 0.01$

sorption values and the Langmuir desorption equation $(\mathrm{R}$ $=0.95-0.99)$ at both the temperatures. Desorption parameters i.e. desorption maxima (' $\mathrm{D}_{\mathrm{m}}$ '), and desorption coefficient (' $\mathrm{K}_{\mathrm{d}}$ ') were also reported (Table 6). Previous studies [23] also reported a significant $(p \leq 0.05)$ correlation between $\mathrm{Pb}$ desorption and Langmuir desorption isotherm.

Interestingly, although we observed higher amount of ' $D_{m}$ ' values for the Palampur as well as Jalandhar soils compared to that of Purulia and Pudukkottai soils, the desorption was higher for the last two soils. Less $\Delta \mathrm{G}^{\mathrm{o}}$ values for Purulia and Pudukkottai soil signifies that the sorption process was less spontaneous for them as compared to the other two soils.

\section{CONCLUSION}

In our $\mathrm{Pb}$ sorption and desorption study, performed in four different soils of India, we observed an increase in $\mathrm{Pb}$ sorption at all of these soils with an increase in $\mathrm{Pb}$ application. Thermodynamic parameters revealed that $\mathrm{Pb}$ sorption was an endothermic reaction. We observed an increase in the sorption amount with the increase in temperature. On the basis of isotherm classification described by Giles et al. [22], we observed that our $\mathrm{Pb}$ sorption data followed the ' $L$ ' type of curve, which signifies a strong affinity between metallic cations and the sorbent surface. The sorption data fitted well with Langmuir adsorption isotherms. At both $25^{\circ} \mathrm{C}$ and $45^{\circ} \mathrm{C}$ $\left(\mathrm{R}^{2}=0.96-0.99\right)$. In all the soils, Langmuir sorption maxima ' $b$ ' and bonding energy coefficient ' $k$ ' increased with the increase in temperature. Desorption of sorbed $\mathrm{Pb}$ showed that sorption and desorption did not follow the same pattern. Desorption data also fitted well to Langmuir desorption isotherms $\left(\mathrm{R}^{2}=0.91-0.98\right)$ for all the experimental soils.

The sorption and desorption studies performed to date were mostly in laboratory scale with sampled soil and therefore have disturbed soil profile. On the contrary, field scale study with undisturbed soil column is missing although in-situ study is extremely important, especially for remediation aspects. This is especially true as the factors controlling the sorption and desorption behavior of $\mathrm{Pb}$ in the soil are more varied, less human controlled, and act simultaneously. However, the in-vitro studies 
determining the fate of heavy metals like $\mathrm{Pb}$ could be an initial step to understand the environmental processes. Therefore, with the knowledge and concept of laboratory analyses, in-situ field study related to heavy metal sorption is required under various environmental conditions.

\section{ACKNOWLEDGEMENTS}

Grateful acknowledgement is extended to Punjab Agricultural University, India, for providing laboratory facility. Indian Council of Agriculture Research provided fellowship to the graduate student (Sudarshan Dutta) to complete the research. Authors show special gratitude to H. S. Hundal, PhD, Department of Soils, and S. S. Bhardwaj (Phd), Department of Chemistry, Punjab Agricultural University; Pritha Dey, Department of Bioinformatics, Sikkim Manipal University of Health Science \& Technology, and Obaidur Rahaman, Chemistry Department, University of Delaware for their overall support.

\section{REFERENCES}

[1] Adhikari, T. and Singh, M.V. (2003) Sorption characteristics of lead and cadmium in some soils of India. Geoderma, 114, 81-92. doi:10.1016/S0016-7061(02)00352-X

[2] Mouni, L., Merabet, D., Robert, D. and Bouzaza, A. (2009) Batch studies for the investigation of the sorption of the heavy metals $\mathrm{Pb}^{2+}$ and $\mathrm{Zn}^{2+}$ onto Amizour soil (Algeria). Geoderma, 154, 30-35.

[3] Singh, S.P., Ma, L.Q. and Harris, W.G. (2001) Heavy metal interactions with phosphatic clay: Sorption and desorption behavior. Journal of Environmental Quality, 30, 1961-1968. doi:10.2134/jeq2001.1961

[4] Strawn, D.G. and Sparks, D.L. (2000) Effect of soil organic matter on the kinetics and mechanisms of $\mathrm{Pb}$ (II) sorption and desorption in soil. Soil Science Society of America Journal, 64, 144-156.

[5] Aziz, H.M.A. (2005) Sorption equilibria of lead (II) on some Palestinian soils-the natural ion exchangers. Colloids Surfaces A: Physicochemical and Engineering Aspects, 264, 1-5. doi:10.1016/j.colsurfa.2004.11.001

[6] Jurinak, J.J. and Bauer, N. (1956) Thermodynamics of zinc adsorption on calcite, dolomite and magnesite type minerals. Proceedings Soil Science Society of America, 20, 466-471.

[7] Eick, M.J., Peak, J.D., Brady, P.V. and Pesek, J.D. (1999) Kinetics of lead adsorption/desorption on goethite: Residence time effect. Soil Science, 164, 28-39.

[8] Sparks, D.L. (2003) Environmental soil chemistry. 2nd Edition, Academic Press, New York.

[9] McBride, M.B. (1999) Chemisorption and precipitation reactions. In: Summer, M.E., Ed., Handbook of Soil Science, CRC Press, Boca Raton, Florida.

[10] Sparks, D.L. (1989) Kinetics of Soil Chemical Processes. Academic Press, New York.
[11] Gajbhiye, K.S. and Mandal, C. (2006) Agro-ecological zones, their soil resource and cropping systems. Internet Available:

http://www.indiawaterportal.org/sites/indiawaterportal.or g/files/01jan00sfm1.pdf

[12] Dutta, S.K., Singh, D. and Sood, A. (2011) Effect of soil chemical and physical properties on sorption and desorption behavior of lead in different soils of India. Soil Sediment Contamination: An International Journal, 20, 2011. Accepted, In press.

[13] Tessier, A.P., Campbell, G.C. and Bisson, M. (1979) Sequential extraction procedure for the speciation of particulate trace metals. Analytical Chemistry, 51, 844-851.

[14] Lindsay, W.L. and Norvell, W.A. (1978) Development of DTPA soil test for zinc, iron, manganese and copper. Soil Science Society of America Journal, 42, 421-428. doi:10.2136/sssaj1978.03615995004200030009x

[15] Soon, Y.K. (1981) Solubility and sorption of cadmium in soils amended with sewage sludge. Journal of Soil Science, 32, 85-95.

[16] Boekhold, A.E., Temminghof, E.J.M. and Van-der-Zee, S.E.A.T.M. (1993) Influence of electrolyte composition and $\mathrm{pH}$ on cadmium adsorption by an acid sandy soil. Journal of Soil Science, 44, 85-96. doi:10.1111/j.1365-2389.1993.tb00436.x

[17] Martínez-Villegas, N., Flores-Vélez, L.M. and Domínguez, O. (2004) Sorption of lead in soil as a function of $\mathrm{pH}$ : a study case in México. Chemosphere, 57, 1537-1542.

[18] Singh, B. and Sekhon, G.S. (1977) Adsorption, desorption and solubility relationships of lead and cadmium in some alkaline soils. Journal of Soil Science, 28, 271-275. doi:10.1111/j.1365-2389.1977.tb02235.x

[19] Shaheen, S.B. (2009) Sorption and lability of cadmium and lead in different soils from Egypt and Greece. Geoderma, 153, 61-68.

[20] Appel, C. and Ma, L.Q. (2002) Concentration, pH and surface charge effects on cadmium and lead sorption in three tropical soils. Journal of Environmental Quality, 31, 581-589. doi:10.2134/jeq2002.0581

[21] Dutta, S.K., Srinidhi, H.V., Kanrar, B. and Singh, D. (2007) Effect of $\mathrm{pH}$ on sorption and desorption behavior of lead in three different soils of India. Environmental Ecology, 25, 337-340.

[22] Giles, C. H., D'Silva, A. P. and Easton, I.A. (1974) A general treatment and classification of the solute adsorption isotherm. Journal of Colloid Interface Science, 47, 766-78. doi:10.1016/0021-9797(74)90253-7

[23] Welp, G. and Brümmer, G.W. (1999) Adsorption and solubility of ten metals in soil samples of different composition. Journal of Plant Nutrition and Soil Science, 162, 166-161. doi:10.1071/SR9830515

[24] Padmanabham, M. (1983) Comparative study of the adsorption-desorption behaviour of copper(II), zinc(II), cobalt(II) and lead(II) at the goethite solution interface. Australian Journal of Soil Research, 21, 515-525. 